\title{
Interannual Changes in the Sea of Oman Ecosystem
}

\author{
Sergey A. Piontkovski ${ }^{*},{ }^{1}$, Hamed M.H. Al-Gheilani ${ }^{2}$, Barry P. Jupp ${ }^{3}$, Adnan R. Al-Azri ${ }^{1}$ and \\ Khalid A. Al-Hashmi ${ }^{1}$ \\ ${ }^{I}$ Department of Marine Science and Fisheries, Sultan Qaboos University, P.O. Box 34, Al-Khod 123, Sultanate of Oman \\ ${ }^{2}$ Marine Science and Fisheries Center, Ministry of Agriculture and Fisheries, P.O. Box 467, Muscat 113, Sultanate of \\ Oman \\ ${ }^{3}$ GEO-Resources Consultants, P.O. Box 175, Mina Al Fahal, Muscat 116, Sultanate of Oman
}

\begin{abstract}
Historical data were used to estimate interannual tendencies for the Sea of Oman over the past 50 years. Declining trends were shown for the atmospheric surface level pressure in the region affected by the Siberian High atmospheric anomaly, the zonal component of wind speed, concentration of nitrates, biomass of diatoms and sardine landings. Changes in Zooplankton biomass showed no clear trend. These trends were associated with and accompanied by rising atmospheric temperature, sea surface temperature, annual variability of the kinetic energy of mesoscale eddies, frequency of fish kills (along with the death of other animals- dolphins, turtles, and sea birds) and harmful algal bloom incidents. In terms of interannual coupling between physical and biological processes, the evaluated trends imply that the weakening of the Siberian High atmospheric anomaly results in the decline of the zonal wind speed and a regional increase of air temperature. This in turn increases the temperature in the mixed layer which strengthens thermo-haline stratification of the water column. Increasing stratification prevents the penetration of nutrients into the mixed layer and does not favor the interannual increase of biological productivity, although annual variation of biological productivity has increased, from 1997 to 2008.
\end{abstract}

Keywords: Gulf of Oman, long term changes oceanography, chlorophyll $a$, climate change.

\section{INTRODUCTION}

The north-western part of the Arabian Sea is connected to the Arabian (Persian) Gulf (often just termed The Gulf [1], by the Sea of Oman (previously known as the Gulf of Oman). In terms of geomorphology, this semi-enclosed basin is "the bathymetric triangle" featured by the range of depths to $3,000 \mathrm{~m}$ in its oceanic part, in which a shallow Murray Ridge extends across the mouth of the Sea of Oman (Fig. 1).

The sea is situated in the subtropical zone and has the total area of $94,000 \mathrm{~km}^{2}$. The basin narrows down and gets shallower towards the Strait of Hormuz- the western most boundary of the sea, where the depths of 70-110 m separates it from the inner part of the Gulf, with an average depth of $\sim 35 \mathrm{~m}$.

After oil exports, fisheries is the next important resource for the region, in which the Sultanate of Oman is one of the biggest fish producers [2]. In 2009, the traditional total fish landings were $\sim 158,000$ tonnes with a value of 268 million US dollars [3]. The total biomass of demersal fish in the Sea of Oman is estimated to be $\sim 51,000$ tonnes, with highest values reported for the upper $20 \mathrm{~m}$ layer [3, 4].

Being situated between the shallow high salinity waters of the Arabian Gulf and the deeper Arabian Sea, the Sea of Oman possesses a unique hydrological regime. In winter,

*Address correspondence to this author at the Department of Marine Science and Fisheries, Sultan Qaboos University, P.O. Box 34, Al-Khod 123, Sultanate of Oman; Tel: +(968) 998 34832; Fax: (+968) 24413418; E-mail: spiontkovski@gmail.com during the Northeast Monsoon, the current transporting the Arabian Sea Water mass from the oceanic regions into the Gulf, is headed towards its inner part along the northern (Iranian) coast. In summer, during the Southwest Monsoon, the sea is influenced by the outflow of high saline Gulf Water Mass. The current exits from the Gulf in the Strait of Hormuz at a depth of $\sim 100 \mathrm{~m}$, cascades down to the bottom and propagates along the Omani coast towards the open Arabian Sea. A well pronounced density front separates high saline deep water in the Gulf from fresher surface waters in the Sea of Oman [5]. Strong vertical gradients and baroclinic instability of the flow exiting the Strait results in mesoscale eddies denoted for the central part of the Gulf.

In a simplified way, for the ecosystem analysis, the thermo-haline structure of waters might be treated as the two layer system with a picnoclyne and the oxycline- below $\sim 50$ $\mathrm{m}$, where the oxygen concentration exhibits a two to threefold drop to highly depleted levels of $<1.5 \mathrm{mg} \mathrm{O}_{2} \mathrm{l}^{-1}[6]$. The upper layer is the Indian Ocean water mass entering the sea in the form of surface current. The high salinity dense waters from the Arabian Gulf form the second layer in which the maximum salinity is in a range of 40.0-40.5 psu [7, 8].

The confluence of currents (off the Arabian Gulf and the Oman Coastal Current propagating along the Omani coast from the Somalia region) forms the frontal zone near the promontory of Ras Al Hadd. This zone, existing during summer and decaying by the end of fall, serves as the liquid boundary between the Arabian Sea and the Sea of Oman. The front also generates cyclonic and anticyclonic eddies which are mostly active throughout the summer and fall 


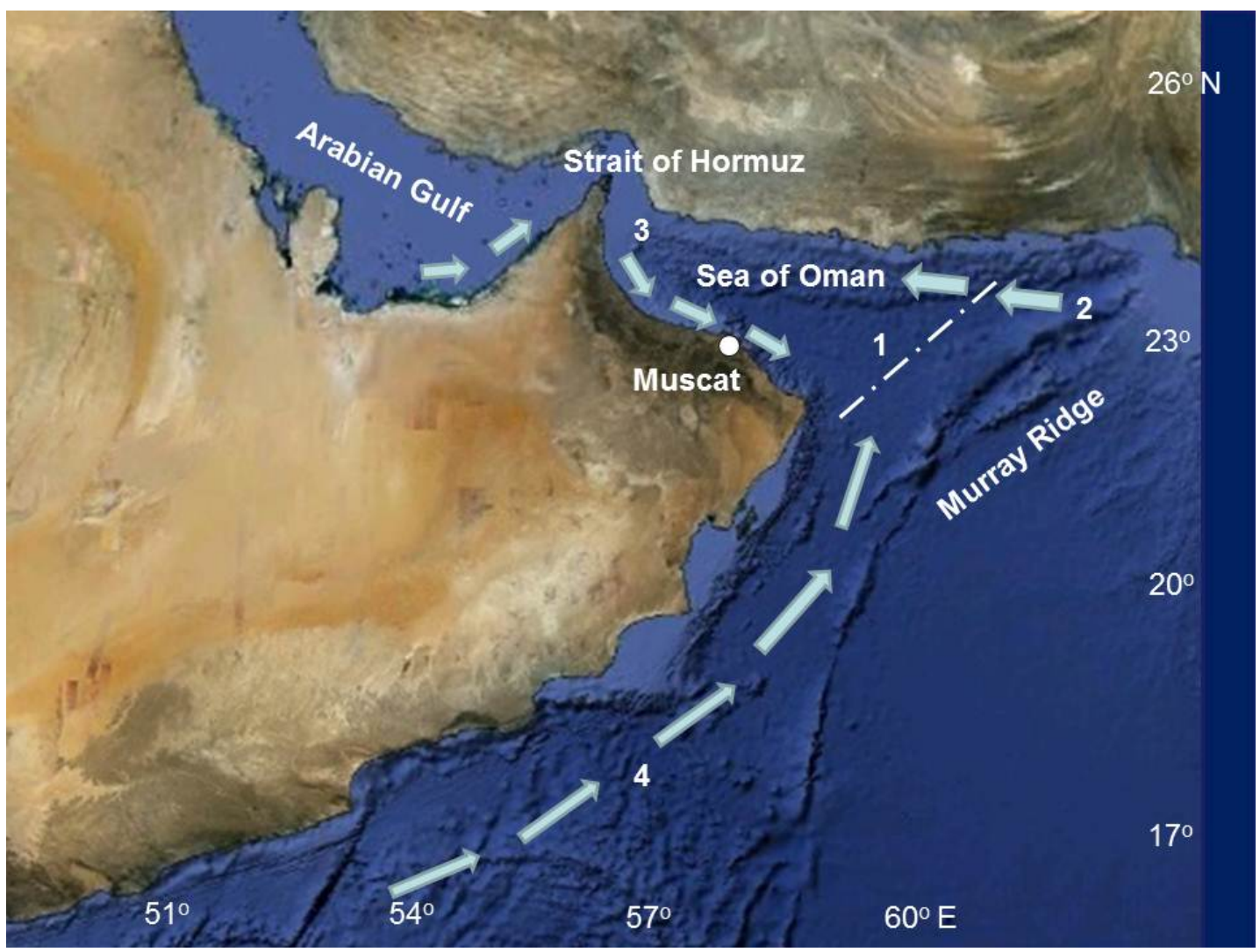

Fig. (1). The Sea of Oman region. Background image: three-dimensional bathymetric map (www.earth.google.com). Dashed and dotted line demarcates the location of the Ras Al Hadd frontal zone (1). Dashed lines (2-4) indicate direction of the main currents (in summer through fall period). (2): inflow of the Indian Ocean Water mass, (3): outflow of the (Arabian Gulf) Persian Gulf Water mass, and (4): Oman Coastal Current.

periods. The size of eddies is comparable to the width of the sea, so they mediate the basin scale mixing. In addition to the formation of eddies within the Sea of Oman, some of them enter the basin from the Arabian Sea.

As far as seasonal variations are concerned, the most prominent feature of the Sea of Oman is the seasonal upwelling along the Iranian coast, with a peak in FebruaryMarch, although the onset of the Northeast monsoonal winds could occur in December. During the Northeast Monsoon, the Oman Coastal Current reverses to southeastward flow.

The atmospheric and hydrographic regimes of the region are both subjected to gradual interannual changes associated with an interannual variability in the strength of monsoonal winds, in turn mediated by the strength of the atmospheric anomalies, of which the most pronounced one is the Siberian High [9-11]. The El-Nino Southern Oscillation and the Indian Ocean Dipole also influence the region, although their epicenters are much more distant.

Despite the numerous studies dealing with seasonal dynamics, the interannual change of the oceanic marine ecosystem is poorly understood for the region but historical data enable some assessment of these changes. Early oceanographic cruises were carried out in the 1950's by Japanese expeditions [12]. In 196624 hydrographic stations were monitored in the cruise conducted by the Russian R/V Mikhail Lomonosov [13]. In the next decade, the Indian R/V Darshak (1974) and Norwegian R/V Dr. Fridtjof Nansen (1975) continued hydrographic surveys in the region [14,
15]. From 1980 through 1997, a number of cruise stations were analyzed by Russian, American, German, British, and Pakistani expeditions [16-19]. The latest comprehensive survey of the Arabian Gulf we are aware of was undertaken in 2006 by the ROPME program, with over 100 oceanographic stations over the Arabian Gulf, of which 29 were situated in the Sea of Oman (http://www.ropme.com/ program2.html).

By using part of these historical data available to us, for example on remote sensing, as well as ongoing sampling and modeling, we attempted an evaluation of interannual trends in some basic physical, chemical and biological characteristics of the Sea of Oman. This incorporates data on the sea level pressure, wind speed, sea surface temperature, kinetic energy of mesoscale eddies, temperature in the mixed layer, concentration of nitrates in the mixed layer, chlorophyll $a$ concentration, the biomass of diatoms, zooplankton biomass, frequency of algal blooms and fish kill incidents, and annual landings of sardines.

\section{METHODS}

Data on the zonal and meridianal components of wind speed over the period 1948 - 2009 were retrieved from the NCAR/NCEP reanalysis database [20], in which the daily averages of wind speed at $10 \mathrm{~m}$ above sea level were extracted for the Sea of Oman region with coordinates 22.5$25.0^{\circ} \mathrm{N} ; 57.5-60.0^{\circ} \mathrm{E}$. 
As far as data on onboard measurements are concerned, a number of expeditions dealt with sampling in the Sea of Oman. The earliest accessible data on vertical profiles of temperature go back to 1950 when oceanographic stations were carried out in the Gulf of Oman by the Japanese research vessel Umitaka Maru and some others [12]. Since that time and up to 1992, Japan has deployed a series of expeditions which analyzed 1100 oceanographic stations in the Sea of Oman region. We used part of these data, which were complemented by recent measurements, to estimate interannual trend in the upper $20 \mathrm{~m}$ layer.

Satellite derived $(9-\mathrm{km}$ spatial resolution SeaWIFS and MODIS Aqua) monthly Level-3 products for sea surface temperature and chlorophyll $a$ concentration were employed, to assemble time series (1997-2009). These products are available from the National Aeronautics and Space Administration (NASA) Ocean Color Group (http://oceancolor.gsfc. nasa.gov). Monthly time series of chlorophyll $a$ and sea surface temperature were acquired using the GES-DISC Interactive Online Visualization and Analysis Infrastructure software as part of the NASA's Goddard Earth Sciences Data and Information Services Center.

The sea surface height anomalies (required to estimate the kinetic energy of eddies) were produced from TOPEX/ Poseidon, Jason-1 and Jason-2 altimeter data and acquired from the Archiving, Validation and Interpretation of Satellite Oceanographic data center website (http://www.aviso. oceanobs.com). The assessment of the kinetic energy of eddies was based on the altimeter-derived sea surface heights for the western Arabian Sea $\left(18-25^{\circ} \mathrm{N}, 58-62^{\circ} \mathrm{E}\right)$, for the period of 1997-2009. The methodology of calculations of eddy kinetic energy per unit mass was that used by $\mathrm{R}$. Sharma, et al. [21]. In developing the algorithm it is believed that the mean component of the ocean current contains less energy than the time-varying component. The meridional component of the geostrophic current was given by

$$
v=(g / f)(\partial \sigma / \partial x)
$$

where $\sigma$ is the sea surface height with respect to the geoid representing the sum of the large-scale component associated with mean circulation and the mesoscale component associated with eddy circulation.

The mean component might be removed by subtracting it from the average sea surface height:

$$
\sigma^{\prime \prime}(\Theta, \phi, t)=\sigma(\Theta, \phi)-\sigma^{\prime}(\Theta, \phi, t)
$$

where $\Theta, \phi, \mathrm{t}$ is location at time $\mathrm{t} ; \sigma(\Theta, \phi)$ is the mean sea surface height over longer duration.

Ascending and descending tracks have been rotated by an angle such that the tracks are parallel to latitude. The transformation leads to constant longitude at each point of the track. The slope along the transformed axis of the ascending and descending altimeter tracks is given by

$$
\Delta\left(\partial \sigma^{\mathrm{i}} / \partial x\right)=\left(\partial \sigma^{\mathrm{i}} / \partial x\right)-(\partial \sigma / \partial x)_{m}
$$

where $x$ is the distance along the transformed axis, the first term on the right-hand side is the sea surface slope of repeat cycle $i$, and $m$ is the averaging period. The eddy velocity perpendicular to the $\mathrm{x}$ axis is given by

$$
\Delta v_{\mathrm{y}}^{\mathrm{i}}=(\mathrm{g} / \mathrm{f}) \Delta\left(\partial \sigma^{\mathrm{i}} / \partial x\right)
$$

The root mean square velocity variability is

$$
\mu^{2}\left(v_{\mathrm{y}}\right)=\left(\Delta v_{\mathrm{y}}^{\mathrm{i}}\right)^{2} / n
$$

where $\mathrm{n}$ is the number of repeat slopes. $E_{e}$ is approximately the average of eddy kinetic energy $-E K E /$ mass in the $x$ and $y$ directions:

$$
E_{e}=0.5\left[\mu^{2}\left(v_{\mathrm{y}}\right)=\mu^{2}\left(v_{\mathrm{y}}\right)=\mu^{2}\right] .
$$

Monthly time series on concentration of nitrate and mixed layer depth were retrieved from the NASA Ocean Biogeochemical Model, which is a coupled three-dimensional 14 vertical layer model incorporating general circulation, biogeochemical, radiative components and assimilating monthly global products [22]. The model is driven by wind stress, shortwave radiation and sea surface temperature. The assimilation process has an algorithm of constant readjustment of the model parameters, based on the chlorophyll data acquired by satellite sensors [22, 23]. It is assumed that oceanic radiation is driven by water scattering, absorption, dissolved organic matter, and optical properties of the phytoplankton groups. The estimates of the sea surface nitrates are based on the algorithms linking the shipboard with remotely sensed data [24].

Plankton samples were collected in the Bandar Khayran Bay $\left(23^{\circ} 31^{\prime} \mathrm{N}, 58^{\circ} 44^{\prime} \mathrm{E}\right)$, which is the largest semi-enclosed bay on the northern coast; with an approximate surface area of $4 \mathrm{~km}^{2}$ and an average depth of $10 \mathrm{~m}$. Samples for chlorophyll $a(250-1000 \mathrm{ml})$ were filtered through a Whatman $\mathrm{GF} / \mathrm{F}$ filters and the phytopigments were extracted in $10 \mathrm{ml}$ of $90 \%$ acetone solution under cold and dark conditions for 24 hours. The chlorophyll $a$ concentration was estimated using a 10 AU Turner Designs Fluorometer following the methods described by Tett [25]. The fluorometer was calibrated using pure chlorophyll $a$ as a standard, following the method described in Parsons, et al. [26].

The phytoplankton samples were collected by Niskin sampler and stored in dark glass bottles $(50$ to $100 \mathrm{ml})$ into which 5 to 10 drops of acid Lugol's solution [27] were added. The entire sample was transferred into graduated cylinders and allowed to settle overnight. The upper layer of seawater in the measuring cylinder was siphoned off using a tube, one tip of which was covered with a $15 \mu \mathrm{m}$ mesh net to concentrate the sample to $20 \mathrm{ml}$. The concentrated subsample was then transferred into sedimentation chambers to settle overnight before counting using inverted microscopy [28]. Cell density was counted by transferring $1 \mathrm{ml}$ replicates of the concentrated sample onto a Sedgewick Rafter counting chamber and identification was based on standard keys in most cases to the species level.

In collecting zooplankton, Bongo nets (mesh size: $150 \mu \mathrm{m})$ were equipped with a Hydrobios $\left.{ }^{(}\right)$digital flowmeter) towed obliquely at a speed of one knot from near the bottom to the surface. Samples were transferred to 0.51 bottles and preserved in $5 \%$ borate-buffered formaldehyde. Back in the laboratory, subsamples were processed to the lowest taxa possible and counted under a stereomicroscope.

Oceanographic data were complemented by data on fish kills along the Omani coast, available from the archives of the Marine Science and Fisheries Research Center (Muscat, Oman). The early records on fish kill incidents were dated by mid 1970 's. Since then, the monitoring of algal blooms 
and fish kill incidents was set up by the Ministry of Agriculture and Fisheries in over 15 regions along the 1,700 $\mathrm{km}$ of the coast.

Data on industrial and traditional landings for Omani fisheries using a sampling system established by the OmanAmerican USAID project [29] have been regularly collected by the Department of Fisheries Statistics. Data on annual landings of sardines in the Sea of Oman were taken from the annual reports published by the Ministry of Agriculture and Fisheries [3].

\section{RESULTS}

In being positioned at the edge of the northern subtropical zone, the western Arabian Sea (including the Sea of Oman) is subjected to a multilateral impact of atmospheric pressure systems exhibiting pronounced interannual and decadal oscillations. For instance, the region is exposed to the impact of the Siberian High pressure system, the El Nino
Southern Oscillation, the North Atlantic Oscillation, and the Indian Ocean Dipole [11, 30, 31].

Regional orography (ranged from deserts to mountains over $2000 \mathrm{~m}$ ) makes the sea-ocean interactions even more complicated. The above atmospheric phenomena impact the long-term changes of the ecosystem of the western Arabian Sea [30], although we are at the initial state of understanding of this coupling. In the current study we confined our analysis to consideration of the Siberian High which is believed to be one of the powerful anomalies affecting almost the whole Asia and the northern Indian Ocean in winter. The Siberian High is defined by the value above $1028 \mathrm{hPa}$ over the middle to higher Asia continent [32]. In terms of interannual changes, the historical records we found in literature $[9,33]$ and used for regression analysis imply that the Siberian High has a general negative trend from the available data set from 1922 to 2000 (Fig. 2). In order to assess any evidence for the footprints of this trend in the wind field, the zonal component of the wind speed was analyzed.

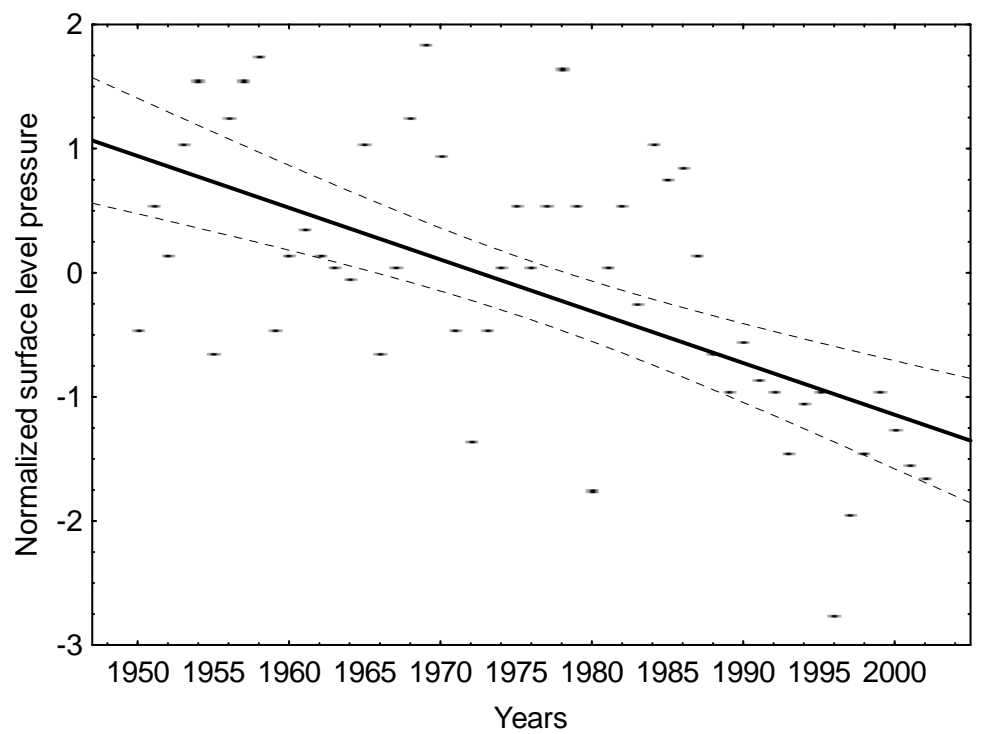

Fig. (2). Interannual trend of the normalized sea level pressure (December-January-February) in the region of the Siberian High (data from [34]). Regression parameters: $r=-0.61, p=0.00002$. Dashed lines $-95 \%$ confidence limit.

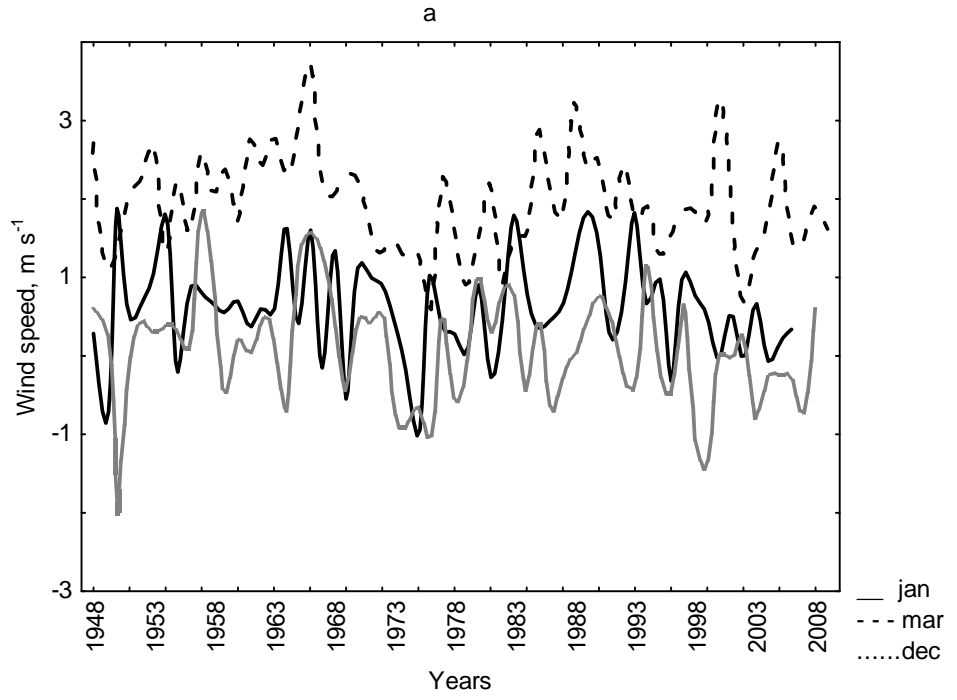

(Fig. (3) Contd..... 


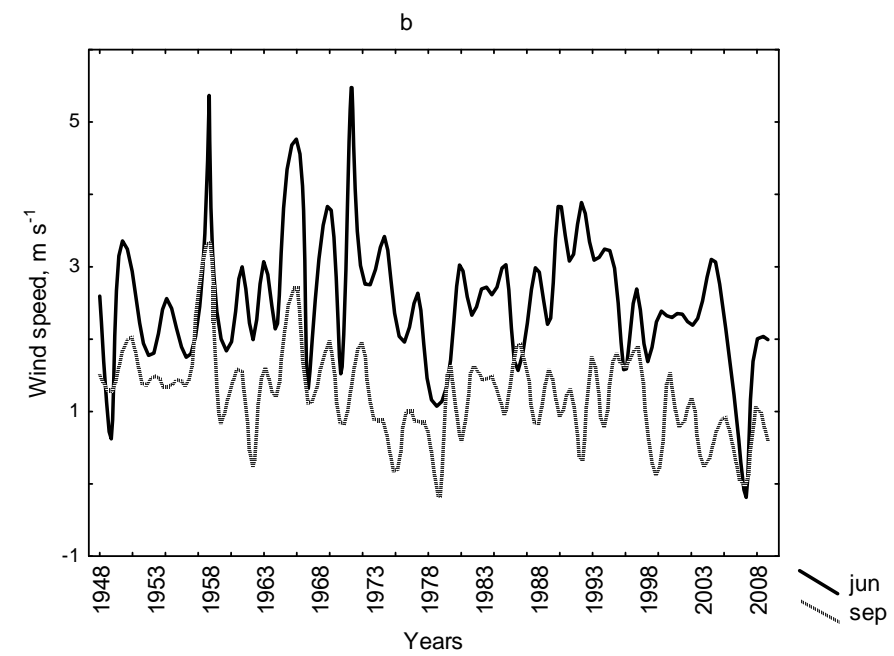

Fig. (3). Interannual changes of the zonal component of wind (U) during winter (a) and summer (b) monsoons. Values are positive when the wind blows from west to east: west wind has a positive zonal component and the east wind is featured by negative zonal component. Curves were smoothed by cubic spline.

The historical NCEP Reanalysis data on the zonal wind speed in the region have exhibited a declining trend, from late 1950 s to 2010 (Fig. 3).
The decline is mostly pronounced for the winter months, experiencing the Northeast Monsoon. By 2010, the wind speed has declined by $\sim 50 \%$, whereas the sea surface
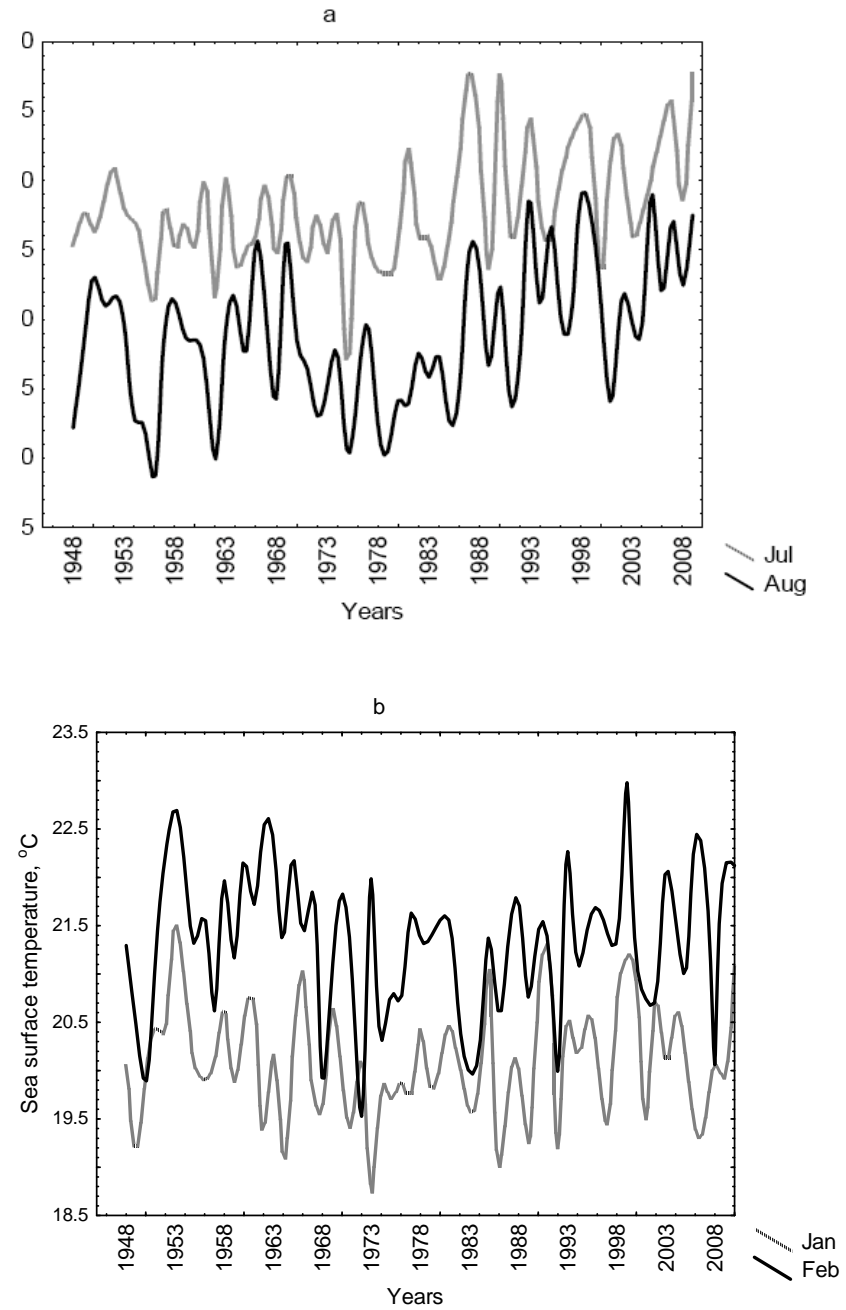

Fig. (4). Interannual changes of sea surface temperature during summer (a) and winter (b) months. Curves were smoothed by cubic spline. 
temperature has increased. This increase was associated with the summer temperatures mainly, from the mid-1970's to the present (Fig. 4a), whereas the winter temperature did not exhibit any pronounced trend in the past 50 years (Fig. 4 b). This resulted in general growth of the SST variation within the annual cycle, due to changes in summer temperatures.

The above results on NCEP database analysis were complemented by historical data on vertical profiles of temperature from the onboard measurements (Fig. 5). These data (picked up for January and February, for the day time casts carried out in the central part of the sea: $57-59^{\circ} \mathrm{E}, 24.5-$ $25.5^{\circ} \mathrm{N}$ ) did not reveal a uniform distribution of temperature vertical profiles over years. However, a general tendency of temperature increase in the upper $20 \mathrm{~m}$ layer was noticed, which fits the trend evaluated for the NCEP data on summer sea surface temperatures (Fig. 4).

The vertical distribution of dissolved oxygen has showed a gradual (two fold) decrease of concentration from the surface to the depth of about $60 \mathrm{~m}$ in summer and $100 \mathrm{~m}$ in winter (Table 1). Below the depth of $120 \mathrm{~m}$ in summer and

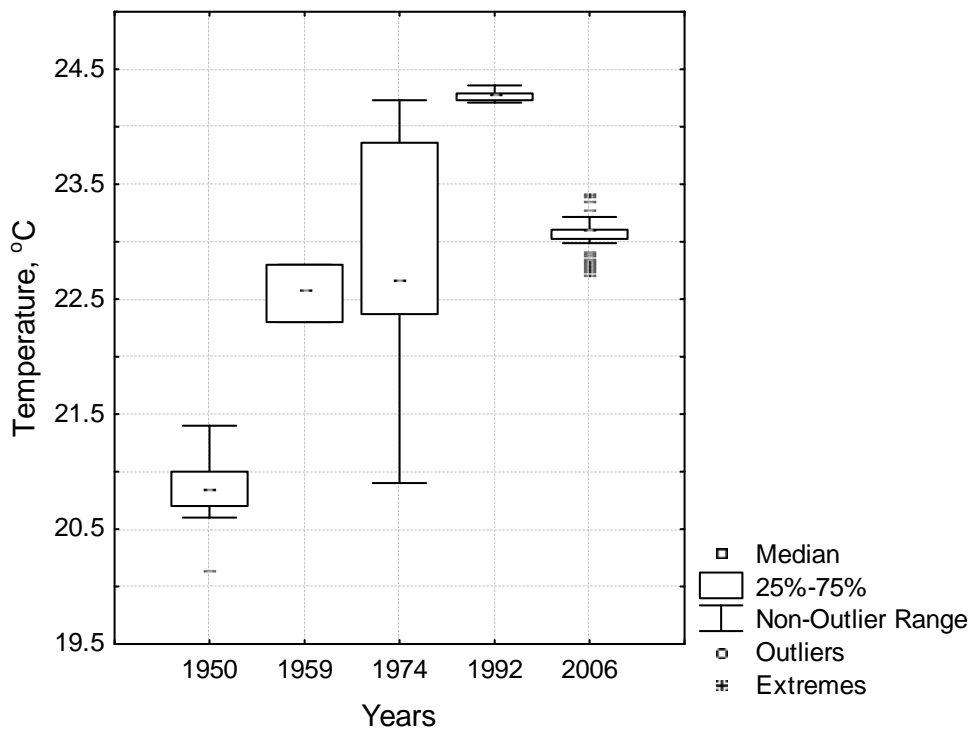

Fig. (5). Annually averaged onboard measurements of temperature in the upper 20m layer in the Sea of Oman (central part), in February through March.

Table 1. An Averaged Vertical Profile of Dissolved Oxygen Concentration in the Sea of Oman (Summer: July-August, 1994; Winter: January-February, 1994. Coordinates: $23-26^{\circ} \mathrm{N}$, 57-60 $\left.^{\circ} \mathrm{E}\right)$

\begin{tabular}{|c|c|c|c|c|}
\hline Depth, $\mathbf{m}$ & $\begin{array}{c}\text { Dissolved oxygen, } \mathrm{mg} \mathrm{l}^{-1} \\
\text { (winter) }\end{array}$ & $\begin{array}{l}\text { Variation coefficient of the } \\
\text { dissolved oxygen, \% (winter) }\end{array}$ & $\begin{array}{c}\text { Dissolved oxygen, } \mathrm{mg} \mathrm{l}^{-1} \\
\text { (summer) }\end{array}$ & $\begin{array}{l}\text { Variation coefficient of the } \\
\text { dissolved oxygen, } \% \text { (summer) }\end{array}$ \\
\hline 0 & 4.77 & 5 & 4.15 & 6 \\
\hline 40 & 4.82 & 2 & 2.58 & 42 \\
\hline 60 & 4.80 & 2 & 1.96 & 54 \\
\hline 120 & 0.77 & 79 & 0.46 & 74 \\
\hline 140 & & & 0.34 & 57 \\
\hline 160 & 0.32 & 73 & 0.31 & 66 \\
\hline 180 & & & 0.33 & 88 \\
\hline 260 & 0.19 & 34 & 0.30 & 76 \\
\hline 280 & & & 0.27 & 86 \\
\hline 300 & 0.27 & 47 & 0.18 & 60 \\
\hline
\end{tabular}




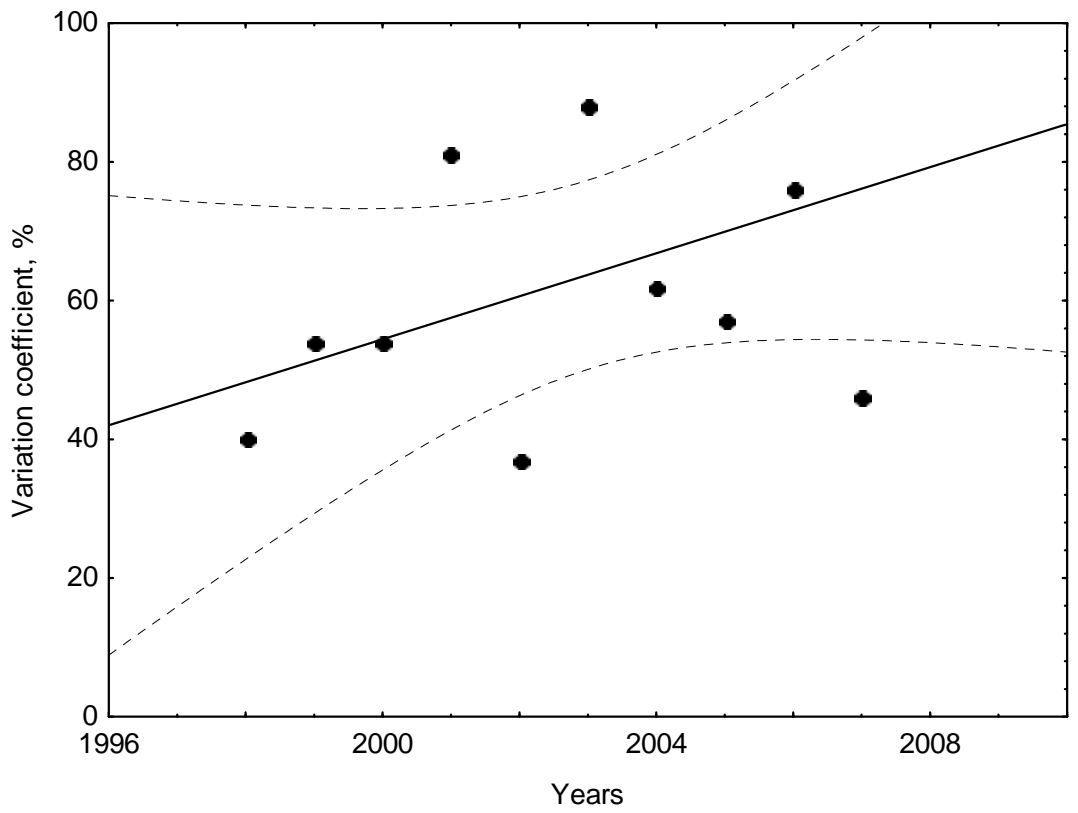

Fig. (6). Interannual changes of the coefficient of variation of chlorophyll $a$ in an annual cycle in the Sea of Oman. $\mathrm{R}=0.48$, $\mathrm{p}=0.14$. Dashed line $-95 \%$ confidence limit.

$150 \mathrm{~m}$ in winter, the concentration was in a region of 0.5 $\mathrm{mg} \mathrm{l}^{-1}$ and less, which is the lethal concentration for the pelagic fish in the Sea of Oman [35]. However, the variation coefficient in the Table 1 implies that this level might be reached at a shallower depth as well.

The range of depths from $200 \mathrm{~m}$ and below corresponds to the location of the Persian Gulf Water Mass, known for its extremely high salinity and low oxygen concentration. The historical data on dissolved oxygen concentration are scarce for the region, which did not allow us a full assessment of interannual trends in this parameter.

In order to make sure the SeaWIFS chlorophyll data retrieved for the Sea of Oman adequately resemble the actual chlorophyll $a$ concentration, we have compared the coastal chlorophyll $a$ sampled at surface in two regions (in Bandar Khayran Bay and Fahal Island, $20 \mathrm{~km}$ apart) with the SeaWIFS monthly chlorophyll $a$ time series retrieved for this region. The days of exact match between daily remotely sensed and onboard chlorophyll measurements were analyzed for the time range from February 2004 to February 2008. The correlation between the onboard and remotely sensed chlorophyll was statistically significant $(\mathrm{r}=0.7$, $\mathrm{p}=0.0015 ; Y=0.317+3.042 X$, where $Y$ is remotely sensed and $X$ is onboard measured chlorophyll $a, \mathrm{mg} \mathrm{m}^{-3}$ ).

The remotely sensed chlorophyll $a$ concentration has not exhibited any pronounced interannual trends. However, a tendency of the annual variation coefficient to increase over years was noticed (Fig. 6).

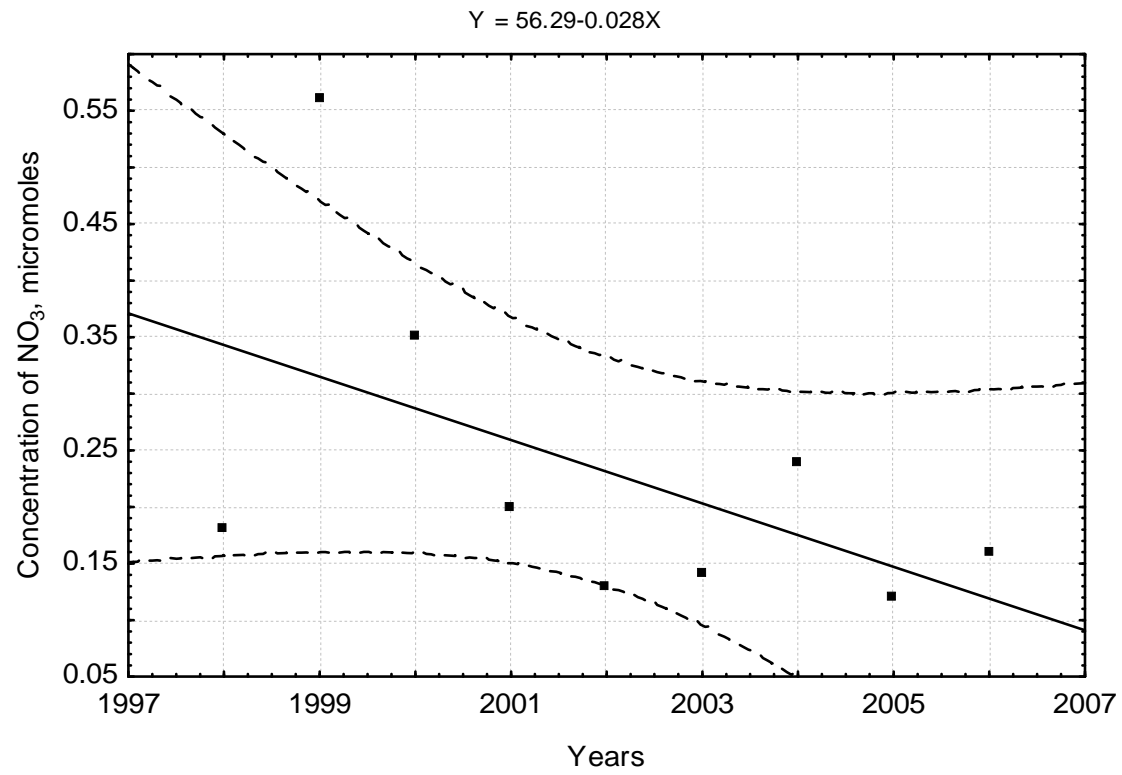

Fig. (7). Interannual changes of nitrates in the Sea of Oman (from NASA Ocean Biogeochemical Model). Dashed line $-95 \%$ confidence limit. 
The variation coefficient, which is the variance to mean ratio, has shown that the fluctuation of chlorophyll within its annual cycle has increased. In order to understand physicochemical dynamics underlying this increase, the NASA Ocean Biogeochemical Model was employed. The model was based on the assimilation of wind stress, shortwave radiation and SST. The model resembles 14 vertical layers, 4 groups of phytoplankton, nutrients (nitrate, regenerated ammonium, silica, and iron), 3 pools of detritus, and a group of herbivores. The assimilation process has an algorithm of constant readjustment of the model parameters, based on the chlorophyll data acquired by satellite sensors [23]. It is assumed that oceanic radiation is driven by water scattering, absorption, dissolved organic matter, and optical properties of the phytoplankton groups. The estimates of the sea surface nitrates were based on the algorithms linking the shipboard data with remotely sensed data [24]. Interannual changes of nitrate concentration retrieved from the model exhibited a general decline from 1999 and onwards (Fig. 7).

Along with that, interannual changes of diatoms showed a declining trend. The biomass of this group decreased four fold, from 2000 to 2006 (Fig. 8). The general decrease of biomass has been accompanied by a declining variability within an annual cycle.

To a certain extent, the modeled declining trend was confirmed by actual data on diatom abundance obtained by coastal sampling, in which; from 2004 to 20010, a monthly

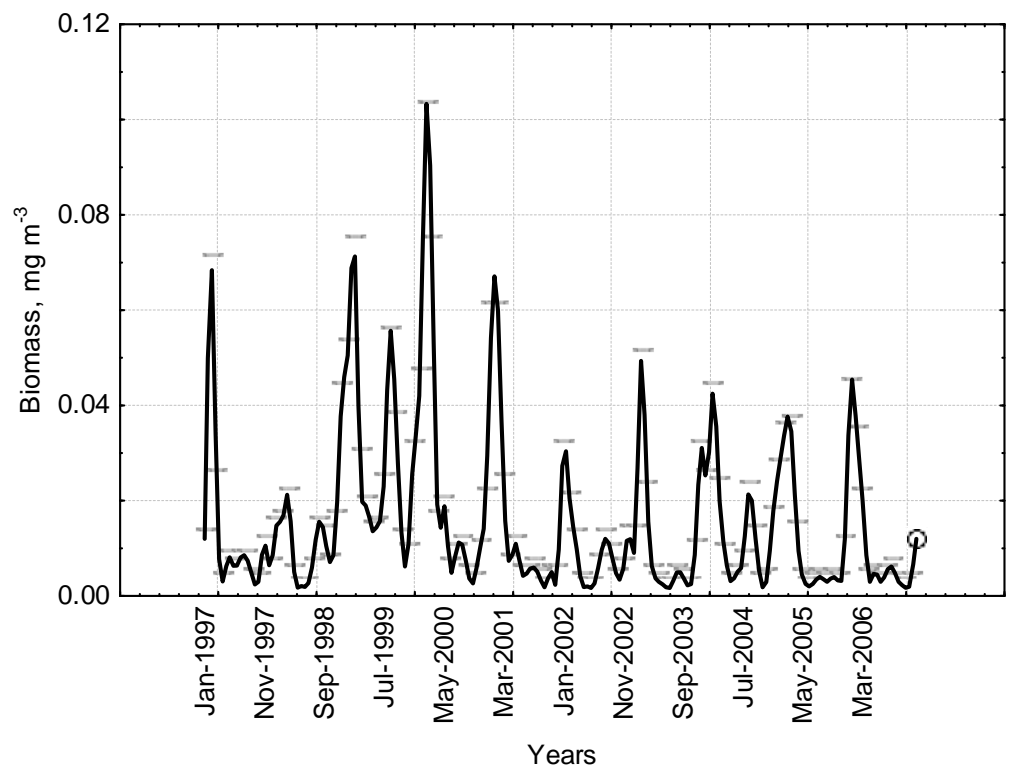

Fig. (8). Interannual changes of diatom biomass in the Sea of Oman (NASA Ocean Biogeochemical Model).

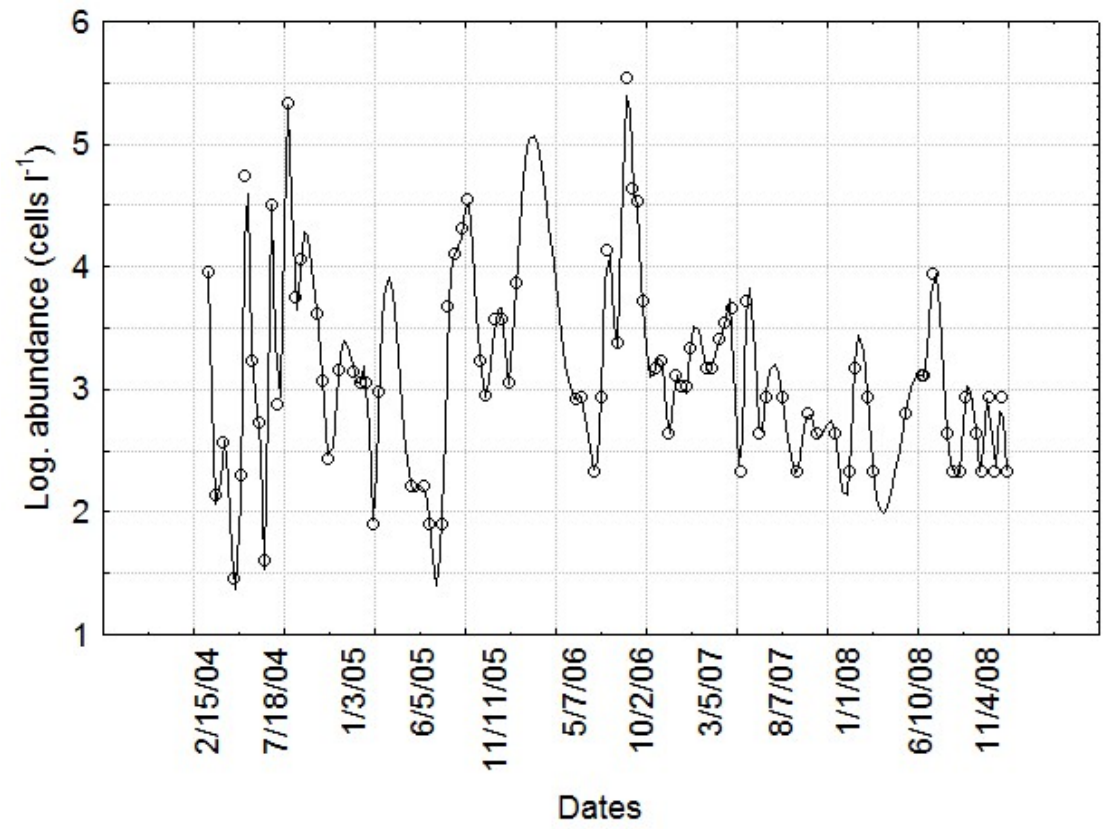

Fig. (9). Monthly changes of diatom total abundance in the Bandar Khayran Bay (1m depth). 
sampling of phytoplankton was carried out near Muscat. The samples processed to the species level covered the period from February 2004 to December 2008 (Fig. 9).

In this plot, the curve linking data points was smoothed by the cubic spline [36]. It appeared that the total abundance of diatoms showed a tendency to decline. A general decrease of diatom abundance has been accompanied by a declining variability within an annual cycle. The genera mostly contributing to the total diatom abundance were Prorocentrum, Nitzschia, Rhizosolenia, Scripsiella, and the Pennate diatoms.

We hypothesized that the other factor inducing a rising trend of chlorophyll annual variability might be a powerful field of mesoscale eddies. These eddies are fairly numerous in the Sea of Oman. A number of them are generated by the confluence of the Oman Coastal Current (fed by the Somali current coming from the south) and the current flowing out of the Arabian Gulf eastward, along the southern coast of the Sea of Oman. Our assessments have shown that in the Sea of Oman, the variation coefficient of the kinetic energy of eddies has linearly increased from 1996 to 2008 (Fig. 10).

From the ecological point of view, this means that the diversity of situations with mesoscale convergences and divergences has increased. Indirectly, this has resulted in a more variable annual cycle of chlorophyll $a$ over years (Fig. 6). The absence of any pronounced trend of chlorophyll $a$ in the Sea of Oman lead us to undertake similar research for the adjacent area. The western Arabian Sea bounded by $54-60^{\circ}$

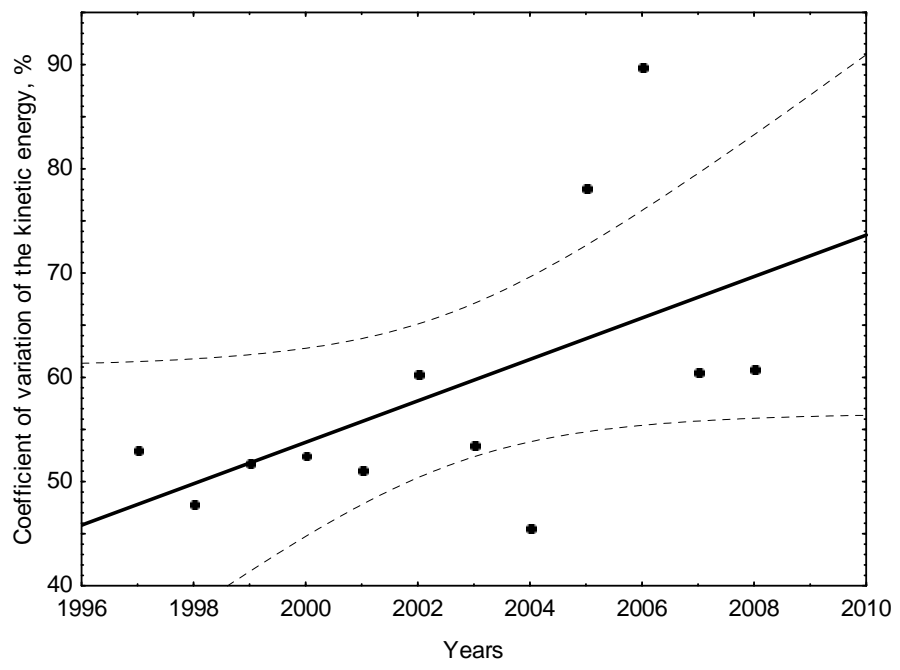

Fig. (10). Interannual changes of the variation of kinetic energy of eddies in an annual cycle. Dashed line $-95 \%$ confidence limit.

b

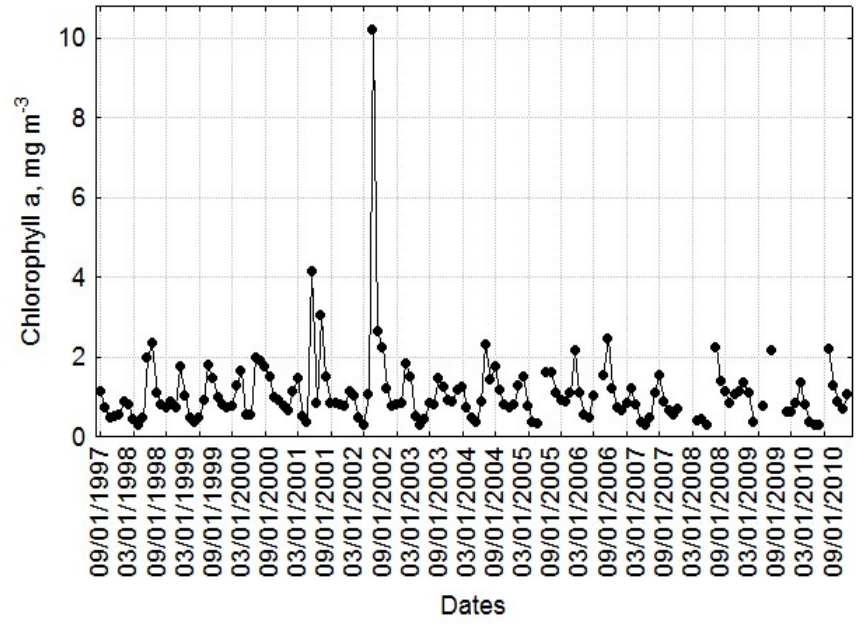

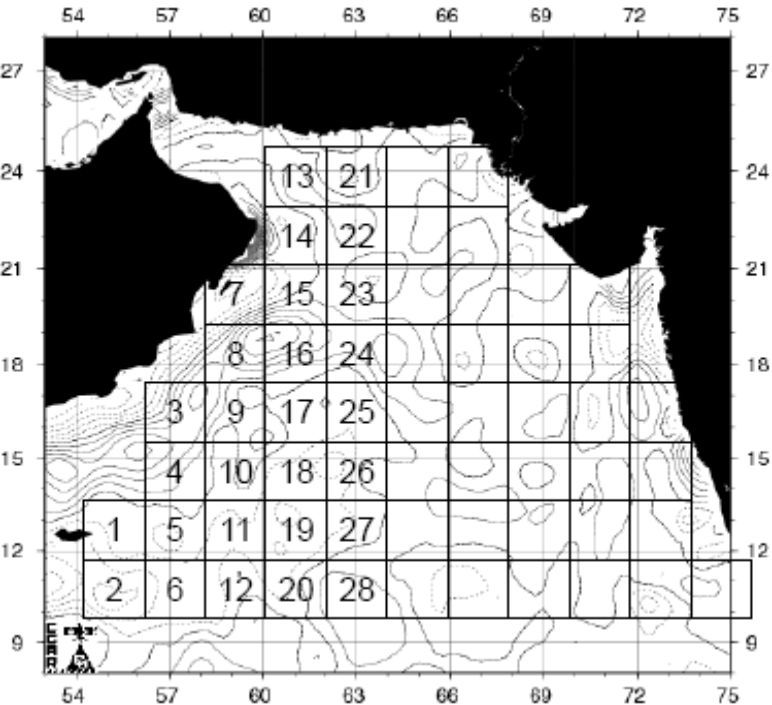

Fig. (11). Monthly time series of chlorophyll $a$ (a) over the western part of the Arabian Sea divided in 28 2-degrees squares (b). The plot (a) covers the upper part of this area $\left(15-25^{\circ} \mathrm{N}\right)$. The background isolines: sea surface heights $(\mathrm{cm})$ exemplifying gradients of surface currents during North East monsoon (June, 2009). Spatial distribution of sea surface heights was acquired using the GES-DISC Interactive Online Visualization and Analysis Infrastructure software as part of the NASA's Goddard Earth Sciences Data and Information Services Center. 
$\mathrm{E}$ and $10-25^{\circ} \mathrm{N}$ was divided into 28 2-degrees squares (Fig. 11 b).

For each square, over the period 1997-2009, satellite derived (9-km spatial resolution SeaWIFS) monthly average time series for chlorophyll were used [37]. This time series indicated no pronounced tendencies of chlorophyll $a$ to increase over the past 12 years. Some of 2-degrees regions (located close to the Omani coastal upwelling) exhibited huge variation within an annual cycle whereas others did not. Overall, the fluctuations observed seem to reflect the seasonal variability with no pronounced interannual trend, which we illustrate with an averaged plot (Fig. 11a) covering the upper 142 -degrees squares $\left(15-25^{\circ} \mathrm{N}\right)$.

We did not find sufficient data on zooplankton to allow statistically reliable evaluation of long-term changes in the Sea of Oman over the past 60 years. There are fragmented reports on zooplankton sampling available for assessment from a number of expeditions carried out by Russian, American, and Pakistani scientists in the period 1960's, to the 1990's. However, these data were collected mostly by different type of nets equipped with different mesh size, which made it hard to compare.

Along the Omani coast, data from comparable sampling accounts were analyzed over the period 2005-2008. Taxonomical processing of these samples has indicated no marked changes in species composition over years. Oncaea sp, Penilia avirostris, Microsetella rosea Parvocalanus elegans, Oithona nana, O.brevicornis, and Temora turbinata were the most abundant zooplankton species in the sampled period. These species are the small-size organisms with a dominant body length of $0.5 \mathrm{~mm}(0.7-0.9 \mathrm{~mm}$ in case of $T$. turbinata).

The above mentioned scarcity of zooplankton data available for the Sea of Oman has forced us to seek for historical data for the adjacent region- which is the northwestern Arabian Sea (Table 2).

Table 2. Estimates of Zooplankton Biomass during the Northeast Monsoon Period for the North-Western Arabian Sea from the Layer of 0-100 m

\begin{tabular}{|c|c|c|c|}
\hline Year & Zooplankton ${\mathbf{~ m g ~} \mathbf{~ m}^{-\mathbf{3}}}$ & Mesh Size $\boldsymbol{\mu \mathbf { m }}$ & References \\
\hline \hline 1960 & $100-150$ & $112-142$ & {$[38]$} \\
\hline 1980 & 128 & $112-142$ & {$[39]$} \\
\hline 1990 & $180-200$ & 142 & {$[40]$} \\
\hline 1997 & 135 & 153 & $\begin{array}{c}{[41]: \text { S7, TN045, }} \\
\text { US JGOFS }\end{array}$ \\
\hline
\end{tabular}

We selected data collected by nets with more or less comparable mesh size for the NE monsoon period. We calculated (where necessary) the values of zooplankton wet biomass by using the ratio of mesozooplankton carbon to wet weight, or displacement volume to wet weight- both reported for the tropical ocean [42]. The data, obtained over a period of almost 40 years, showed no pronounced trend in changes of zooplankton biomass.

In the Sea of Oman, the sardine population is one of the major consumers of mesozooplankton. The annual landing of sardines in Oman ranges between 7000 and 18000 metric tones. This comprises $\sim 49 \%$ of total landings in the Muscat region. The analysis of data over the years has indicated an approximate $40 \%$ decline of sardine landing (Fig. 12).

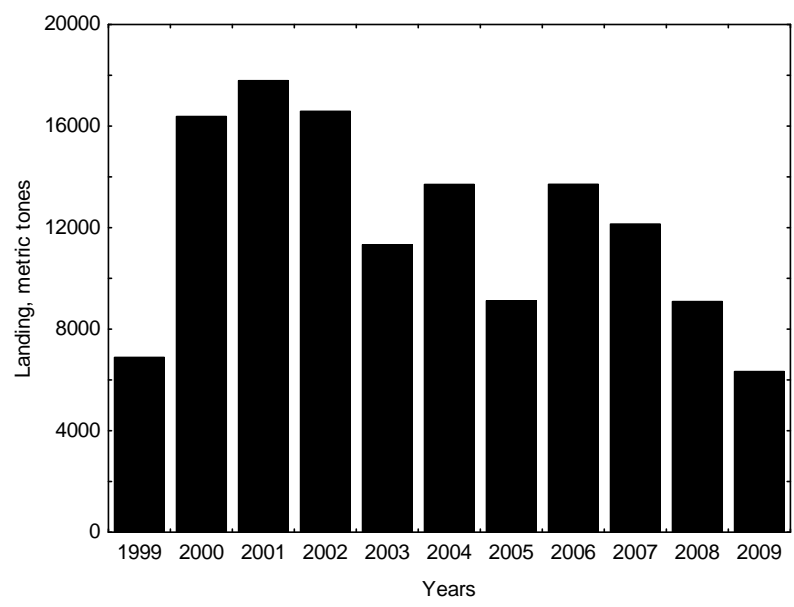

Fig. (12). Annual landing of sardines in the Muscat region. Data from [3].

It should be noted that the number of fishermen's boats in the region did not show any increase, with the reported number of 1858 boats in 2004 and 1624 boats in 2008, for the Muscat region [3].

The monitoring of the fish kill incidents along the Omani coast, carried out by the Ministry of Agriculture and Fisheries, from 1970s through the present time, has resulted in historical data with the most data available for the Muscat region. These data were complemented by records on algal bloom occurrence. A number of algal blooms along the coast has developed into a harmful phase at times, resulting in fish kill incidents. From the mid 1970's to 2010, approximately 70 algal blooms were recorded along the Omani coast, and some $40 \%$ of these blooms reached the harmful algal bloom category (HAB) accompanied by mass mortality of fish and other marine organisms. Thus in November-December 2001, in Al Sharqiya and Al Wusta regions, 40 tons of fish and at least 250 individual green turtles Chelonia mydas as well as dolphins and birds were found dead. High concentrations of the toxic dinoflagellate Karenia selliformis with over $2 \times 10^{6}$ cells per liter were found. This apparently was the first time that sea turtle or dolphin mortalities were associated with such a bloom.

In April 2004, 100 tons of sardines were reportedly killed by a HAB event progressing along the coast of Duqm. In one of the recent incidents, 70 tons of fish (Sparus aurata) perished in aquaculture cages. This HAB (with the core near Qurayat), took place in November 2008 and was accompanied by a gradual depletion of oxygen (from 7.0 to 0.1 $\mathrm{mg}^{-1}$ ) that caused mass mortality. In order to estimate any interannual changes, data on fish kill and HAB incidents were averaged over decades (Fig. 13).

It appeared that the tendency to increase was well pronounced for both characteristics. A significant feature implied by this plot was the ratio between HABs and fish kills incidents. Throughout four decades, the frequency of HABs has exceeded the frequency of fish kills. This means that not 


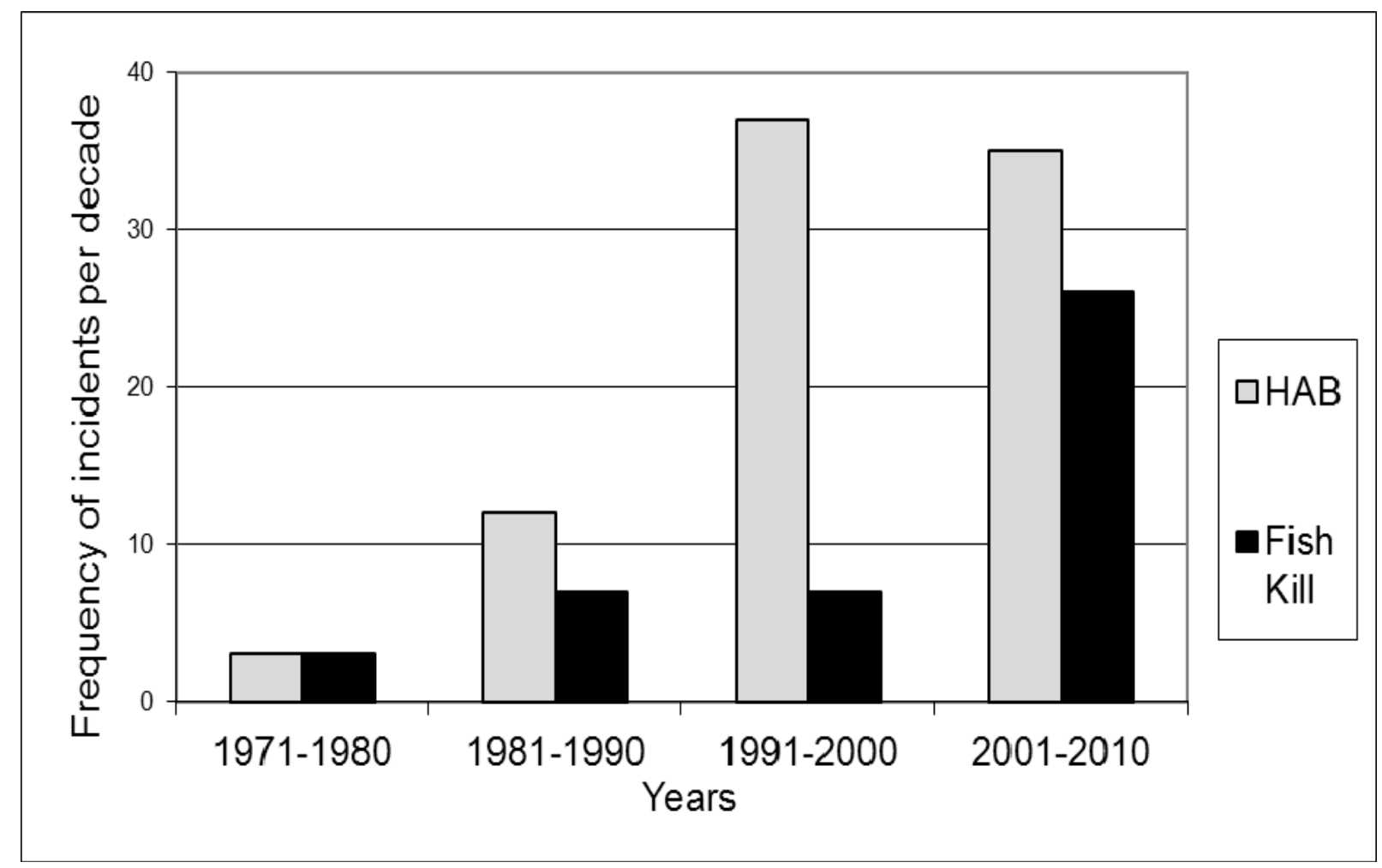

Fig. (13). Interannual changes of fish kill and harmful algal bloom incidents in the Sea of Oman.

all HABs had caused fish kills. Nevertheless, the causal pattern of this relationship is apparent throughout decades of observations; in the latest decade, more algal blooms had reached the HAB category and the number of fish kills had increased and became more associated with HABs, compared to the three previous decades.

\section{DISCUSSION}

In analyzing "a big picture of the ocean" based on historical data, Levitus, et al. [43] reported a positive linear trend in heat content over the period 1955-2008. For the 0$700 \mathrm{~m}$ layer of the world ocean, the percent variance accounted for by the linear trend was $85 \%$.

In the case of regional scales, the situations and rates might be different. The warming trend in atmospheric temperature across the Middle East has shown an increase of $0.07{ }^{\circ} \mathrm{C}$ per decade over the period 1951-1990 [44]. The atmospheric temperature over the Arabian Gulf, including the Sea of Oman, is rising as well [45-48] with an averaged projected increase of up to $4{ }^{\circ} \mathrm{C}$ by the end of the century [49]. Regionally, the warming trend of the dry-season temperatures has shown an increase of $0.17{ }^{\circ} \mathrm{C}$ per decade for the Bahrain region [50]. Interesting differences were reported seasonally within this trend, for the dry versus wet seasons. While the warming rate for the dry summer season was up to $0.24{ }^{\circ} \mathrm{C}$ per decade, there was a cooling tendency for the wet season months.

It appears from the present study that similar seasonal differences are seen in changes of the sea surface temperature in the Sea of Oman (Fig. 4). We have shown a positive trend of increasing summer temperatures versus a lack of such a trend for the winter data. This should lead to an increase of the variation of the sea surface temperature within the annual cycle. The widening of the variation within the annual cycle over the years was evaluated for the chlorophyll $a$ and variability of the kinetic energy of eddies (Figs. 6 and 10), which is fairly high for the region; the ADCP data showed that in the Omani waters, over $90 \%$ of the total kinetic energy was associated with the eddy field [51]. It is possible that the variance in eddies (cyclonic versus anticyclonic ones) originating in or entering the Sea of Oman has increased over the years. This would influence the variation of sea surface temperature, kinetic energy, and chlorophyll $a$, with all three exhibiting rising trends.

A declining trend was observed for a number of major parameters in the Sea of Oman ecosystem. Thus decline was seen in the availability of nitrates, the variability and biomass of diatoms, zooplankton biomass (not well confirmed), and sardine landings. These declining trends were associated with and accompanied by rising atmospheric temperature, sea surface temperature, variability of the kinetic energy of eddies, frequency of fish kills and harmful algal bloom incidents.

As far as the Omani algal blooms are concerned, the dinoflagellate Noctiluca scintillans dominates in the historical records of the species causing blooms [52]. We pointed out that the causal relationship between HABs and fish kill in Omani waters has increased over recent decades (Fig. 13). In part, this might be associated with toxic impacts from HABs. Many dinoflagellate species are reportedly toxic. Toxins such as okadaic acid, domoic acid, palytoxin, 
saxitoxins, and tetrodotoxin, may be produced in large amounts by these species and transferred along food chains $[53,54]$.

The other species (i.e. Noctiluca scintillans) could cause fish kills indirectly, through the toxicity of excreted ammonium [55]. Furthermore, being heterotrophic, this species is capable to consume diatoms (Thelassiosira rotula, Pseudonitzchia sp), dinoflagellates (Dinophysis sp, Prorocentrum sp.) and green algae (Dunaliella tertiolecta) all found in the food vacuoles of Noctiluca [56]. These consumed species may then produce toxins causing fish kill incidents.

In terms of key components of phytoplankton community, the decline of diatom biomass (Fig. 8) is accompanied by the increasing role of dinoflagellates in seasonal blooms over years - the event reported for the northern Arabian Sea [57]. Perhaps, a similar trend is taking place in the Sea of Oman. The declining availability of nitrates (Fig. 7), associated with rising temperatures and thermo-haline stratification, favors the dinoflagellate populations more than the diatoms. Through the property of being less heavy but more abundant, the dinoflagellates might contribute to the increased amplitude of the chlorophyll annual variability over the years (Fig. 6). The other (dynamical) mechanism affecting this increase is a rising activity of mesoscale eddies in the western Arabian Sea (Fig. 10).

Due to "semi-inland location" and complex bathymetry, the trends reported for the Sea of Oman might be quite different from what is observed in the western Arabian Sea, in particular in the region of "classical" Omani upwelling developed along the coast during summer Southwest Monsoon. This means that a shift of dominant scales of variability takes place along the coast. In the Sea of Oman and the north-western Arabian Sea, the annual cycle mediated by the winter Northeast Monsoon is the dominant one. Southward along the coast, as well as in the western Arabian Sea, the biannual cycle of chlorophyll $a$ and sea surface temperature is getting more pronounced, due to combined effect of Southwest and Northeast Monsoons [58].

Mesoscale eddies are just one of the forms of dynamic events taking place in Omani waters. The mesoscale plumes of productive waters and spatial displacements of currents (offshore and onshore) might have significant ecological footprints as well. The mesoscale variation of oxygen depletion and the issue of existence of the interannual trend in this event are among the most important ones for the ecology of the sea. In the Sea of Oman, the time of coastal hypoxia reaching the upper mixed layer could last from hours to weeks [59, 60].

In terms of the "big picture", a trend in salinity increase was reported for the period 1950-2008 for the poorly ventilated deep north Indian Ocean in the range of densities driven by the Red Sea Water mass and the Gulf Water mass $[61,62]$. Salinization might be one of the processes forcing the oxygen minimum zone to expand in size, from 1960s to the present time [63].

It seems that the oxygen minimum zone reported for the central Arabian Sea has a much larger scale. This zone impinges on the Omani shelf and results in a rapid decline of oxygen below the euphotic zone [64-66]. An interesting fact is a heterogeneous spatial distribution of the oxygen minimum layer (off the shelf), which showed an increase of oxygen values from west to east, in the opposite direction to basin scale trends in the northern Indian Ocean [66].

On a mesoscale, due to impact of wind stress, the shoaling of the upper boundary of the oxygen minimum zone along the shelf extending from $\sim 50 \mathrm{~m}$ to the surface, could cause massive fish kills along the Omani coast [60, 67, 68]. Is the shoaling of the oxygen minimum zone taking place on the interannual scale? Intensifying anoxia was reported for the eastern side of the basin- the continental shelf of India, for instance [69]; this issue needs to be investigated for the Oman shelf as well.

As for the interannual scale of salinity increase, any general strengthening of thermo-haline stratification and oxygen depletion should lead to an increase in the incidence of fish kills; this, indeed, has been observed over the past four decades (Fig. 13).

The other source of rising salinity of the Persian Gulf Water mass outflow deals with the anthropogenic impact caused by numerous desalination plants in the Arabian Gulf. The total desalination capacity of these plants contributes $45 \%$ of the world capacity [70]. Values are comparable to a naturally induced variation of salinity in the Gulf, due to evaporation and precipitation [1].

Goes, et al. [71] reported and interannual escalation in the intensity of summer monsoonal winds accompanied by enhanced upwelling along the Omani coast and a $>350 \%$ increase in average summer time phytoplankton biomass (which was assessed by remotely sensed chlorophyll $a$, from 1994 to 2004). This raised the issue of current warming trend in the Northern Hemisphere which could make the Arabian Sea more productive.

The region selected by Goes, et al. [71] for the analysis $\left(52-57^{\circ} \mathrm{E}, 5-10^{\circ} \mathrm{N}\right)$ has covered about $1 \%$ of the Arabian Sea. Our recent studies do not fit the concept of rising productivity [72]; in this cited paper, we analyzed wind speed, sea surface temperature and chlorophyll $a$, on a scale of the whole Arabian Sea, which was divided into 61 2-degrees regions between $54-76^{\circ} \mathrm{E}$ and 10-25 $\mathrm{N}$ (Fig. 9, low panel), of which we show the western part only. Trend analysis was performed on temperature and chlorophyll $a$ time series using the Mann-Kendall test. No positive trends were evaluated, in the SeaWIFS monthly chlorophyll time series for the western Arabian Sea. This means that the Arabian Sea is not getting more productive (as far as the chlorophyll $a$ is concerned as the indicator of biological productivity), and neither has the Sea of Oman. As it has been emphasized above, the productivity of the sea is markedly influenced by the Northeast Monsoon, in which the intensity of the Siberian High plays the major role. The Siberian High has demonstrated a steady decline, in the past five decades [73].

Further investigations of this phenomenon revealed a dramatic trend of $-2.5 \mathrm{hPa}$ per decade in the Siberian High index between 1978 and 2001 with unprecedented (since 1871) low values. The weakening has been confirmed by analyzing different historical gridded data and individual station observations of sea level pressure [33]. The authors also report a statistically significant positive correlation between Siberian High and upper air zonal wind. Overall, 
the weakening of the Siberian High results in the decline of the zonal wind speed and regional increase of air temperature. This in turn increases the temperature in the mixed layer which strengthens thermo-haline stratification of the water column. Increasing stratification prevents the penetration of nutrients into the mixed layer and does not favor the interannual increase of biological productivity. In a light of discussion dealing with current trends of productivity [71] this means that the western Arabian Sea is not getting more productive (as far as the chlorophyll $a$ is concerned as the indicator of biological productivity), and neither is the Sea of Oman.

\section{CONCLUSION}

Historical data were used to estimate interannual tendencies for the Sea of Oman over the past 50 years. Declining trends were evaluated for the atmospheric surface level pressure (in the region affected by the Siberian High atmospheric anomaly), the zonal component of wind speed, concentration of nitrates, biomass of diatoms, zooplankton biomass (not well confirmed), and sardine landings. These trends were associated with and accompanied by rising atmospheric temperature, sea surface temperature, annual variability of the kinetic energy of mesoscale eddies, frequency of fish kills and harmful algal bloom incidents. In terms of interannual coupling between physical and biological processes, the trends analyzed imply that the weakening of the Siberian High atmospheric anomaly results in the decline of the zonal wind speed and regional increase of air temperature. This in turn increases the temperature in the mixed layer which strengthens thermo-haline stratification of the water column. Increasing stratification prevents the penetration of nutrients into the mixed layer and does not favor the interannual increase of biological productivity, although annual variation of biological productivity has increased, from 1997 to 2008.

\section{ACKNOWLEDGEMENTS}

The present work was supported by research grants from The Research Council (\#ORG/EBR/09/004), and Agricultural and Fisheries Development Fund (Sultanate of Oman). We are grateful to Dr. N. Nezlin (for computations on kinetic energy of eddies), E. Popova, L. Manzhos and L. Kuzmenko for consultations in plankton taxonomy, and anonymous referees for their comments that have helped to improve the manuscript.

\section{CONFLICT OF INTEREST}

None declared.

\section{REFERENCES}

[1] Sheppard C, Al-Husiani M, Al-Jamali F, et al. The Gulf: a young sea in decline. Mar Pollut Bull 2010; 60: 13-38.

[2] Carpenter KE, Krupp F, Jones DA, et al. Living marine resources of Kuwait, Eastern Saudi Arabia, Bahrain, Qatar and UAE. FAO Species Identification Field Guide for Fishery Purposes. Rome: FAO Publication 1997; pp. 23-31.

[3] Fishery Statistics Book. Ministry of Fisheries Wealth, Sultanate of Oman. Muscat 2009.
[4] Valinassab T, Daryanabard R, Dehghani R, et al. Abundance of demersal fish resources in the Persian Gulf and Oman Sea. J Mar Biol Assoc UK 2006; 86: 1455-62.

[5] Swift SA, Bower AS. Formation and circulation of dense water in the Persian/Arabian Gulf. J Geophys Res 2003; 108 (Pt C1): 3004.

[6] El Sarma MI, El Gindy AAH. Vertical distribution and interrelations of oxygen and nutrients in the Arabian Gulf and the Gulf of Oman in summer. Qatar Univ Sci Bull 1990; 10: 445-464.

[7] Brewer PG, Fleer AP, Kadar S, et al. Chemical oceanographic data from the Persian Gulf and the Gulf of Oman. Report WHOI-78-37, Woods Hole 1978.

[8] Chao SY, Kao TW, Al-Hajri KR. A numerical investigation of circulation in the Persian Gulf. J Geophys Res 1992; 97: 11219-36.

[9] Gong DY, Ho CH. The Siberian High and climate change over middle to high latitude. Asia Theor Appl Climatol 2002; 72: 1-9.

[10] Nazemosadat MJ, Ghasemi AR. Quantifying the ENSO-related shifts in the intensity and probability of drought and wet periods in iran. J Climate 2004; 17: 4005-18.

[11] Shinoda T, Hendon HH, Alexander MA. Surface and subsurface dipole variability in the Indian Ocean and its relation with ENSO. Deep Sea Res 2004; 51 (Pt I): 619-35.

[12] Yoshida J, Matsuyama M, Senjyu T, et al. Hydrography in the RSA during the RT/V Umitaka-Maru cruises. In: Otsuki A, Abdulraheem MY, Reynolds RM, Eds. Offshore Environment of the ROPME Sea Area after the war-related oil spill. Tokyo: Terra Scientific Publishing Comp 1998; pp. 1-22.

[13] Artamonov YV. The circulation and structure of water masses of the Arabian Sea based on synoptic surveys. In: Banse K, Piontkovski SA, Eds. The mesoscale structure of the epipelagic ecosystem of the open northern Arabian Sea. Hyderabad: Universities Press 2006; pp. 12-53.

[14] Banse K. Irregular flow of Persian (Arabian) Gulf water to the Arabian Sea. J Mar Res 1997; 55: 1049-67.

[15] Sandven S. Coastal oceanography of the Arabian Sea. University of Bergen, Norway 1979.

[16] Burkill PH, Mantoura RFC, Owens NJP. Biogeochemical cycling in the northwestern Indian Ocean: a brief overview. Deep Sea Res 1993; 40 (Pt II): 643-9.

[17] Khan AJ. Distribution and abundance of fish larvae off the coast of West Pakistan. Mar Biol 1976; 37: 306-24.

[18] Piontkovski SA, Banse K. Overview of results. In: Banse K, Piontkovski SA, Eds. The mesoscale structure of the epipelagic ecosystem of the open northern Arabian Sea. Hyderabad: Universities Press 2006; pp. 1-9.

[19] Smith SL. The Arabian Sea of the 1990s: New biogeochemical understanding. Prog Oceanogr 2005; 65: 113-5.

[20] Kistler R, Kalnay E, Collins W, et al. The NCEP-NCAR 50-year reanalysis: monthly means CD-ROM and documentation. Bull Amer Meteorol Soc 2001; 82: 247-68.

[21] Sharma R, Gopalan AKS, Ali MM. Interannual variation of eddy kinetic energy from TOPEX altimeter observations. Marine Geodesy. USA: Taylor \& Francis Ltd 1999; Vol. 22: pp. 239-48.

[22] Gregg WW. Assimilation of SeaWiFS ocean chlorophyll data into a three-dimensional global ocean model. J Mar Syst 2008; 69: 20525.

[23] Nerger L, Gregg WW. Assimilation of SeaWIFS data into a global ocean-biogeochemical model using a local SEIK filter. J Mar Syst 2007; 68: 237-54.

[24] Goes JI, Gomes HR, Saino T, et al. Exploring MODIS data for estimating sea surface nitrate from space. EOS Trans AGU 2004; 85: 449-64.

[25] Tett P. Plankton. In: Baker JM, Wolff WJ, Eds. Biological surveys of estuaries and coasts. Cambridge: University Press 1987; pp. 32835 .

[26] Parsons T, Maita R, Lalli YCM. A manual of chemical and biological methods for seawater analysis. Oxford: Pergamon Press 1984.

[27] Throndsen J. Preservation and storage. In: Sournia A, Ed. Monographs on oceanographic methodology 6: Phytoplankton Manual. United Nations Educational, Scientific and Cultural Organisation. Paris: UNESCO 1978; pp. 17-26.

[28] Utermohl H. Zur Vervollkommung der quantitativen Phytoplankton Methodik. Mitt Int Ver Limnol 1958; 9: 1-38. 
[29] Mathews CP, Al-Mamry J, Al-Habsy S. Precautionary management of Oman's demersal fishery: 2001: First International Conference on Fisheries, Aquaculture and Environment in the NW Indian Ocean. Muscat, Sultanate of Oman, Sultan Qaboos University 2001; pp. 41-9.

[30] Hood RR, Wiggert JD, Naqvi SWA. Indian Ocean research: Opportunities and challenges. In: Wiggert JD, Hood RR, Naqvi SWA, Brink KH, Smith SL, Eds. Indian Ocean Biogeochemical Processes and Ecological Variability. Geophysical Monograph. Washington: American Geophysical Union 2009; pp. 409-28.

[31] Nezlin NP, Polikarpov IG, Al-Yamani F. Satellite-measured chlorophyll distribution in the Arabian Gulf: Spatial, seasonal and inter-annual variability. Int J Oceans Oceanogr 2007; 2: 139-56.

[32] Gong DY, Wang SW. Long-term variability of the Siberian High and the possible influence of global warming. Acta Geogr 1995; 4: 125-33.

[33] Panagiotopoulos F, Shahgedanova M, Hannachi A, et al. Observed trends and teleconnections of the siberian high: a recently declining center of action. J Clim 2005; 18: 1411-22.

[34] Trenberth KE, Paolino D. The Northern Hemisphere sea-level pressure data set: trends, errors, and discontinuities. Mon Weather Rev 1980; 108: 855-72.

[35] Al Busaidi SS, Al Rashdi KM, Al Gheilani HM, et al. Massive fish mortality during red tide of Masirah Island, Arabian Sea: 2007: The Arabian Seas International Conference on Science and Technology of Aquaculture, Fisheries and Oceanography; 2007 Feb 10-13; Kuwait, Kuwait Institute for Research 2007; pp. 18-24.

[36] De Boor CA. Practical Guide to Splines. Berlin: Springer-Verlag 1978.

[37] Berrick SW, Leptoukh GJ, Farley D, Rui H. Giovanni: a web service workflow-based data visualization and analysis system. IEEE Trans Geosci Remote Sens 2009; 47: 106-13.

[38] Bogorov VG, Vinogradov ME. Some features of distribution of zooplankton biomass in the upper waters of the Indian Ocean in winter 1959. Okenologicheskie Issledovaniya 1961; 4: 66-71 (In Russian).

[39] Samishev EZ. Trends of zooplankton growth in open waters of the Arabian Sea. In: Nelepo DA, Ed. Complex Oceanological Investigations of the Indian Ocean. Sevastopol: Marine Hydrophysical Institute 1981; 124-32 (In Russian).

[40] Piontkovski SA, Melnik TA. Mesozooplankton of the northwestern Arabian Sea. In: Banse K, Piontkovski SA, Eds. The mesoscale structure of the epipelagic ecosystem of the open northern Arabian Sea. Hyderabad: Universities Press 2006; pp. 120-43.

[41] World Ocean Database 2009. NOAA National Oceanographic Data Center. Available from: http://www.nodc.noaa.gov/OC5/WOD/ pr_wod.html. [Updated 2011 Jan 24; cited 2010 Nov 22].

[42] Vinogradov ME, Shushkina EA. Functioning of planktonic communities in the ocean epipelagos. Moscow: Nauka 1987 (In Russian).

[43] Levitus S, Antonov JI, Boyer TP, et al. Global ocean heat content 1955-2008 in light of recently revealed instrumentation problems. Geophys Res Lett 2009; 36: L07608.

[44] Nasrallah HA, Balling RC Jr. Spatial and temporal analysis of Middle Eastern temperature changes. Clim Change 1993; 25: 15361.

[45] Alvi SH. Meteorological characteristics of Oman- case study of some regions: Proceedings of the First Regional Conference in Civil Engineering (RCCE-89); University of Bahrain 1989.

[46] Alvi SH. Climatic changes in Bahrain. GeoJournal 1995; 37: 45-50.

[47] Alvi SH. Investigating Warming Phenomenon: The Arabian Gulf Region: Case Study For Bahrain, Dubai (UAE) And Salalah (Oman): $17^{\text {th }}$ Global Warming International Conference; $2006 \mathrm{Apr}$ 19-21; Miami 2006; pp. 54-8.

[48] Nasrallah HA, Balling RC Jr. Analysis of recent climatic changes in the Arabian Gulf region. Environ Conserv 1993; 20: 223-6.

[49] Meehl GA, Stocker TF, Collins WD. Global climate projections. In: Solomon S, Qin D, Manning M, et al. Eds. Climate Change 2007: The Physical Science Basis. Contribution of Working Group I to the Fourth Assessment Report of the Intergovernmental Panel on Climate Change. Cambridge \& New York: Cambridge University Press 2007; pp. 80-87.
[50] Elagib NA, Abdu AS. Development of temperatures in the Kingdom of Bahrain from 1947 to 2005. Theor Appl Climatol 2010; 101: 269-79.

[51] Flagg C, Kim HS. Upper ocean currents in the northern Arabian Sea from shipboard ADCP measurements collected during 19941996 US JGOFS and ONR programs. Deep Sea Res 1998; 45 (Pt II): 1917-59.

[52] Tangaraja M, Al-Aisry A, Al-Kharusi L. Harmful algal blooms and their impacts in the middle and outer ROPME sea area. Int J Oceans Oceanogr 1997; 2: 85-98.

[53] Deeds JR, Wiles K, Heideman GB, et al. First U.S. report of shellfish harvesting closures due to confirmed okadaic acid in Texas Gulf coast oysters. Toxicon 2010; 55: 1138-46.

[54] Vasconcelos V, Azevedo J, Silva M, Ramos V. Effects of marine toxins on the reproduction and early stages development of aquatic organisms. Mar Drugs 2010; 8: 59-79.

[55] Montani S, Pithakpol S, Tada K. Nutrients regeneration in coastal seas by Noctiluca scintillans, a red-tide causing dinoflagellates. J Mar Biotechnol 1998; 6: 224-8.

[56] Mohamed ZA, Mesaad I. First report on Noctiluca scintillans blooms in the Red Sea off the coasts of Saudi Arabia: consequences of eutrophication. Oceanolagia 2007; 49: 337-51.

[57] Gomes HR, Matondkar SGP, Parab SG, et al. Unusual blooms of green Noctiluca miliaris (Dinophyceae) in the Arabian Sea during the winter monsoon. In: Wiggert JD, Hood RR, Naqvi SWA, Brink KH, Smith SL, Eds. Indian Ocean Biogeochemical Processes and Ecological Variability. Geophysical Monograph. Washington: American Geophysical Union 2009; pp. 347-64.

[58] Piontkovski SA, Al-Azri AR, Al-Hashmi KA. Seasonal and interannual variability of chlorophyll a in the Gulf of Oman compared to the open Arabian Sea regions. Int J Remote Sens 2011; 32: 7703-15.

[59] Al-Azri AR, Piontkovski SA, Al-Hashmi KA, et al. Seasonal cycle of chlorophyll $a$ and physical-biological coupling in the Gulf of Oman. Aquat Ecol 2009; 44: 449-61.

[60] Claereboudt M, Hermosa G, McLean E. Plausible cause of massive fish kill in the Gulf of Oman: 2001: Proceeding of the First International Conference on Fisheries, Aquaculture and Environments in the Northwest Indian Ocean; 2001 Oct 7-10; Oman, Sultan Qaboos University 2001; pp. 23-34.

[61] Durack PJ, Wijffels SE. Fifty-Year trends in global ocean salinities and their relationship to broad-scale warming. J Clim 2010; 23: 4342-62.

[62] Tomcza M, Godfrey JS. Regional Oceanography: An Introduction. New York: Pergamon Press 1994.

[63] Stramma L, Johnson GC, Sprintall J, et al. Expanding oxygenminimum zones in the Tropical Oceans. Science 2008; 320(5867): 655-8.

[64] Herring PJ, Fasham MJR, Weeks AR, et al. Across-slope relations between the biological populations, the euphotic zone and the oxygen minimum layer off the coast of Oman during the Southwest Monsoon (August 1994). Prog Oceanogr 1998; 41: 69-109.

[65] Levin LA, Gage JD, Martin C, et al. Macrobenthic community structure within and beneath the oxygen minimum zone, NW Arabian Sea. Deep Sea Res 2000; 47 (Pt II): 189-226.

[66] Reichart GJ, Schenau SJ, de Lange GJ, et al. Synchroneity of oxygen minimum zone intensity of the Oman and Pakistan Margins at sub-Milankovitch time scales. Mar Geol 2002; 18: 403-15.

[67] Herring D. Fish kill in the Gulf of Oman. A space-based diagnosis. 2002 Aug 14; Available from: http://earthobservatory.nasa.gov/ Features/oman [cited 2010 Nov 08].

[68] Morrison JM, Codispoti LA, Smith SL, et al. Oxygen minimum zone in the Arabian Sea during 1995. Deep-Sea Res 1999; 46 (Pt II): 1903-31.

[69] Naqvi SWA, Jayakmar DA, Narvekar PV, et al. Increased marine production of $\mathrm{N}_{2} \mathrm{O}$ due to intensifying anoxia on the Indian continental shelf. Nature 2004; 8: 346-9.

[70] Lattemann S, Höpner T. Environmental impact and impact assessment of seawater desalination. Desalination 2008; 220: 1-15.

[71] Goes IJ, Prasad GT, Helga HR, et al. Warming of the Eurasian landmass is making the Arabian Sea more productive. Science 2005; 308: 545-7. 
[72] Piontkovski SA, Claereboudt MR. Interannual changes of the Arabian Sea productivity. Mar Biol Res 2012; 8: 189-94.
[73] Daoyi G, Shaowu W. Influence of Arctic Oscillation on winter climate over China. J Geogr Sci 2003; 13: 208-16.

Received: September 04, 2011

Revised: February 15, 2012

Accepted: February 17, 2012

(C) Piontkovski et al.; Licensee Bentham Open.

This is an open access article licensed under the terms of the Creative Commons Attribution Non-Commercial License (http://creativecommons.org/licenses/by$\mathrm{nc} / 3.0 /$ ), which permits unrestricted, non-commercial use, distribution and reproduction in any medium, provided the work is properly cited. 